\title{
Education Research: Online Alzheimer education for high school and college students
}

\author{
A randomized controlled trial
}

\author{
Nabeel Saif, MS, Kellyann Niotis, MD, Moises Dominguez, MD, John F. Hodes, BS, Michael Woodbury, BS, \\ Yasmin Amini, BS, George Sadek, BA, Olivia Scheyer, BA, Emily Caesar, BA, Hollie Hristov, FNP, \\ Newman Knowlton, MS, Paige Lee, Mark McInnis, BA, and Richard S. Isaacson, MD
}

Neurology ${ }^{\circledR}$ 2020;95:e2305-e2313. doi:10.1212/WNL.0000000000009859

\section{Abstract}

\section{Objective}

Alzheimer disease $(\mathrm{AD})$ risk factors are present throughout the lifespan. This randomized controlled trial evaluated the effectiveness of various online education strategies concerning $\mathrm{AD}$ risk reduction and brain health in younger populations.

\section{Method}

High school and college students were recruited via social media (Facebook and Instagram) to join $\mathrm{AlzU}$.org, an evidence-based education portal, and were randomized to 1 of 4 courses: highly interactive webinar lessons narrated by actor Seth Rogen (celebrity webinar) or a physician (doctor webinar), minimally interactive video lessons with Seth Rogen (celebrity video), or minimally interactive video lessons (control). Surveys were administered at baseline and postcourse. The primary outcome was change in knowledge of $\mathrm{AD}$ risk reduction assessed by pre vs post lesson quiz scores. Secondary outcomes included change in awareness of $\mathrm{AD}$ research, hopefulness about $\mathrm{AD}$, interest in pursuing health care, willingness to volunteer, and likelihood of recommending AlzU.org.

\section{Result}

A total of 721 participants joined. A total of 281 (38.9\%) completed the course. Among college students, quiz score improvements were greater in celebrity webinar and celebrity video vs doctor webinar and control. Among high school students, no differences were found in quiz scores. In both groups, celebrity webinar, celebrity video, and doctor webinar resulted in greater improvements in awareness that nutrition and exercise may reduce $\mathrm{AD}$ risk vs controls. Among college students, celebrity webinar and celebrity video group participants felt more hopeful about the future of $\mathrm{AD}$ and more likely to recommend $\mathrm{AlzU}$.org vs doctor webinar and control participants. Among college students, celebrity webinar, celebrity video, and doctor webinar participants were more willing to volunteer for $\mathrm{AD}$ causes and pursue health care careers vs controls.

\section{Conclusion}

Online education involving a celebrity may be an effective strategy for educating college students about $\mathrm{AD}$ risk reduction strategies. Further studies are warranted in high school students.

\author{
Correspondence \\ Dr. Isaacson \\ rii9004@med.cornell.edu
}




\section{Glossary}

$\mathrm{AD}=$ Alzheimer disease $\mathbf{M C Q}=$ multiple choice question .

Alzheimer disease $(\mathrm{AD})$ is one of the greatest global health challenges of this century, as over 47 million people are estimated to have $\mathrm{AD}$ or a related dementia. ${ }^{1}$ There has been limited progress in developing $\mathrm{AD}$ treatments, but modifiable risk factors continue to be identified throughout the lifespan. For example, early-life education (age $<18$ ) has been identified as one of the most significant determinants, influencing relative risk by $60 \% .{ }^{2}$ Population-attributable risk models estimate that managing such risk factors (e.g., hypertension, insulin resistance, physical inactivity) may prevent up to onethird of dementia cases, suggesting that early lifestyle changes involving diet and exercise are key components in $\mathrm{AD}$ risk reduction. ${ }^{2}$ Nevertheless, studies have shown a distinct knowledge gap in college students about $\mathrm{AD}$ risk factors. ${ }^{3}$ Considering this, along with the fact that 1 in 6 millennial caregivers cares for a person with dementia, it is essential to educate younger generations about $\mathrm{AD}$ as well as risk reduction strategies. ${ }^{1}$

As students grow accustomed to web-based learning, online education may be a useful method to broadly promote healthy behaviors. ${ }^{4}$ Studies have shown that similar interventions can improve knowledge of exercise strategies and general nutrition, but an e-learning intervention specifically focused on $\mathrm{AD}$ and brain health has not yet been studied. ${ }^{5,6}$

Alzheimer's Universe (AlzU.org) is an online portal providing evidence-based educational resources on $\mathrm{AD}$ and multidomain strategies for risk reduction. Although a prior study demonstrated that AlzU.org improved knowledge of $\mathrm{AD}$ risk reduction, this study population had a mean age $>65$ years. ${ }^{7}$ To evaluate the effectiveness of various e-learning formats on teaching high school and college students about $\mathrm{AD}$ and brain health, AlzU.org partnered with Hilarity for Charity, a nonprofit organization founded by Seth and Lauren Rogen.

Multiple studies have shown that including a celebrity can improve a health campaign's impact on the attitudes and perceptions of adolescents and young adults. ${ }^{8,9}$ In turn, this can result in behavioral change as suggested by the theory of planned behavior, which states that an individual's attitudes, perceived behavioral control, and normative beliefs are essential factors in determining behavioral change. ${ }^{10}$

To build upon this prior research, the primary objective of this study was to evaluate whether the inclusion of a celebrity can enhance online learning of $\mathrm{AD}$ and $\mathrm{AD}$ risk reduction in high school and college students. The secondary aim was to compare the relative effectiveness of highly interactive webinar lessons vs minimally interactive video lessons that included a celebrity.

\section{Methods}

\section{Participants}

Between October 10, 2018, and February 28, 2019, high school and college students were recruited via social media (Facebook.com and Instagram) to join AlzU.org. ${ }^{11}$ Posts were promoted with targeted advertising to ages 14-24 with expressed interest in "Alzheimer disease." A total of 406 users enrolled in the high school course and 315 users enrolled in the college course. Participants aged $>24$ were excluded from the study.

\section{Study design}

In this randomized controlled trial (ClinicalTrials.gov NCT03149380), participants were randomized to 1 of 4 lesson groups using a random number generator: (1) highly interactive webinar lessons narrated by actor Seth Rogen (celebrity webinar), (2) highly interactive webinar lessons narrated by a physician (doctor webinar), (3) minimally interactive video lessons narrated by Seth Rogen (celebrity video), or (4) minimally interactive noncelebrity/nondoctor narrated video lessons (control). Informed consent was obtained (IRB 1311014539).

\section{Curriculum development}

The course includes 3 lessons: (1) What is Alzheimer's? (2) Stages of Alzheimer's; and (3) Overview of Brain Health. Lesson content was created by a multidisciplinary team of $\mathrm{AD}$ health care professionals, including 4 neurologists $(2 \mathrm{AD}$ specialists, 2 with graduate training in medical education), 2 instructional designers, and a professional graphic designer. Each lesson ( $\sim 1,500$ words) was edited by a professional medical writer with experience in lay public education. Lessons were reviewed by focus groups and refined accordingly.

Lessons consisted of 2 possible formats: webinar and video. Webinar lessons were made highly interactive, capitalizing on strengths of the e-learning design software Articulate Studio. These lessons required continuous user engagement to advance through the lesson, and included various interaction styles, along with periodic intracontent quiz questions that require the user to select an answer to proceed. ${ }^{12}$ Video lessons required substantially less interaction. Video lessons had the narrator ask intraperiodic quiz questions, but learners did not have the option to select a specific answer. Rather, there was a 5-second pause for learners to consider the options before the narrator would reveal the correct answer. Question examples are included in appendices e-1 and e-2 (links.lww.com/WNL/B129).

Control lessons consisted of time-neutral, noninteractive, noncelebrity/nondoctor video lessons that included congruent imagery and educational content. The control served as an 
"active" placebo, rather than a traditional placebo, which would not include any related educational content in an effort to formally study pedagogical effects of specific lesson formats and degree of interactivity. ${ }^{13}$

\section{Study procedures}

Immediately after joining AlzU.org, participants were administered a precourse survey (via surveymonkey.com) to collect demographic data and baseline knowledge/beliefs regarding $\mathrm{AD}$. This survey consisted of 29 questions, including 5-point Likert scales and multiple-choice and fill-in questions. After completing the survey, participants were redirected back to AlzU.org to complete the lessons in sequential order (lessons unlocked sequentially upon completion of prior module). Before and after each lesson, a quiz of 3 multiple choice questions (MCQs) was administered. After completing the 3-lesson course, a postcourse survey was administered. To improve lesson completion rates, additional email reminders were sent.

\section{Outcomes}

The primary outcome was change in knowledge of $\mathrm{AD}$ risk reduction strategies and brain healthy behaviors, assessed by total MCQ correct pre vs post lesson quizzes. Changes in quiz scores were compared across all 4 groups.

Secondary outcomes included (1) change in awareness of prevalent $\mathrm{AD}$ research findings (exercise and nutrition may reduce $\mathrm{AD}$ risk), (2) hopefulness about the future of $\mathrm{AD}$ research, (3) interest in pursuing a career in health care, (4) willingness to volunteer for $\mathrm{AD}$-related causes, and (5) likelihood of recommending the course to others.

\section{Statistical analyses}

Paired $t$ test procedures were used to compare pre vs post lesson quiz scores and pre vs post course outcomes. One-way analysis of variance was used to compare differences in pre vs post scores among the lesson groups. In cases where change in score differed significantly between the groups $(p<0.05)$, post hoc $t$ tests were performed to assess for specific group differences.

\section{Results}

\section{Demographic and baseline characteristics}

The mean age was 21.2 years (SD 2.9) for college students and 16.4 years (SD 1.8) for high school students. Female respondents comprised $58.7 \%$ and $64.5 \%$ of the college and high school students, respectively. A majority of college students were Caucasian (58.7\%), whereas high school students consisted of larger minority populations (30.8\% Hispanic) Latino, 18.6\% Asian/Pacific Islander, 32.0\% Caucasian). See table 1 for additional information.

Mean total prelesson quiz scores were 3.7 (SD 2.3) and 4.9 (SD 2.9) of 9 for college and high school students, respectively; these did not differ among the 4 groups in college $(p=0.67)$ or high school students $(p=0.54)$. Baseline values for awareness that both nutrition and exercise may reduce $\mathrm{AD}$ risk did not differ among the groups in college and high school students.

\section{Lesson completion}

Of 315 college students, 109 (34.6\%) completed the course/ postsurvey. The completion rates were $39.5 \%$ (30 of 83 ), 36.6\% (26 of 71), 33.3\% (24 of 72), and 32.6\% (29 of 89) for the celebrity video, celebrity webinar, doctor webinar, and control, respectively. No differences were found between completion rates.

Of 406 high school students, 172 (42.4\%) completed the course/postsurvey. The completion rates were $47.1 \%$ (48 of 102), $44.2 \%$ (42 of 95), $41.1 \%$ (46 of 112), and 37\% (36 of 97) for the celebrity video, celebrity webinar, doctor webinar, and control, respectively. No differences were found between completion rates.

\section{Quizzes}

In college students, all 4 groups scored higher on the postlesson quizzes (table 2). Difference in quiz score improvement was significant across the 4 groups $(p<0.01)$. Quiz improvements were significantly greater in the celebrity webinar and celebrity video when compared to both the control and the doctor webinar. Improvements did not differ between the doctor webinar and control (table 3 ).

In high school students, all 4 groups scored higher on the postlesson quizzes (table 2). No differences were found among the groups $(p=0.24)$.

\section{Secondary endpoints}

In both high school and college students, the celebrity webinar, celebrity video, and doctor webinar had greater improvements in awareness that both nutrition and exercise may reduce $\mathrm{AD}$ risk vs control. No differences were found among the celebrity webinar, celebrity video, and doctor webinar (table 3).

In college students, the celebrity webinar and celebrity video groups felt more hopeful about the future of $\mathrm{AD}$ research and were more likely to recommend the course vs both the doctor webinar and control participants. The celebrity webinar, celebrity video, and doctor webinar participants were more willing to volunteer for $\mathrm{AD}$-related causes and pursue a career in health care vs controls (table 3 ).

Among high school students, there were no differences in hopefulness about the future of $\mathrm{AD}$ research $(p=0.08)$, interest in pursuing a career in health care $(p=0.19)$, willingness to volunteer for $\mathrm{AD}$-related causes $(p=0.35)$, and likelihood of recommending the course $(p=0.18)$.

\section{Discussion}

To our knowledge, this is the first randomized study to investigate the effectiveness of various online educational strategies to inform college and high school students about $\mathrm{AD}$ risk. $\mathrm{Al}-$ though little difference was seen among the courses in high 
Table 1 Baseline demographics of college and high school students

\begin{tabular}{|c|c|c|c|c|c|}
\hline Variable & Celebrity webinar & Celebrity video & Doctor webinar & Control & Total \\
\hline College & $n=26$ & $n=30$ & $n=24$ & $n=29$ & $n=109$ \\
\hline Age, y, mean & 21.3 & 22.0 & 20.7 & 21.1 & 21.3 \\
\hline \multicolumn{6}{|l|}{ Year of education } \\
\hline Freshman & $3(11.5 \%)$ & $3(10 \%)$ & $3(12.5 \%)$ & $6(20.7 \%)$ & 15 (13.8\%) \\
\hline Sophomore & $4(15.4 \%)$ & $8(26.7 \%)$ & $5(20.8 \%)$ & $6(20.7 \%)$ & $23(21.1 \%)$ \\
\hline Junior & $6(23.1 \%)$ & $6(20 \%)$ & $4(15.4 \%)$ & $7(24.1 \%)$ & $23(21.1 \%)$ \\
\hline Senior & $8(30.8 \%)$ & $8(26.7 \%)$ & $5(20.8 \%)$ & $7(24.1 \%)$ & $28(25.7 \%)$ \\
\hline Other & $5(19.2 \%)$ & $2(6.7 \%)$ & $5(20.8 \%)$ & $2(6.9 \%)$ & $14(12.8 \%)$ \\
\hline \multicolumn{6}{|l|}{ Sex } \\
\hline Male & $9(34.6 \%)$ & $14(46.7 \%)$ & $9(37.5 \%)$ & $13(44.8 \%)$ & $45(41.3 \%)$ \\
\hline Female & $17(65.4 \%)$ & $16(53.3 \%)$ & $15(62.5 \%)$ & $16(55.2 \%)$ & 64 (58.7\%) \\
\hline \multicolumn{6}{|l|}{ Race } \\
\hline Caucasian & $14(53.8 \%)$ & $19(63.3 \%)$ & $15(62.5 \%)$ & $16(55.2 \%)$ & 64 (58.7\%) \\
\hline Hispanic/Latino & $4(15.4 \%)$ & $1(3.3 \%)$ & $3(12.5 \%)$ & $3(10.3 \%)$ & $11(10.1 \%)$ \\
\hline African American & $4(15.4 \%)$ & $3(10 \%)$ & $1(4.2 \%)$ & $3(10.3 \%)$ & $11(10.1 \%)$ \\
\hline Asian/Pacific Islander & $2(7.7 \%)$ & $2(6.7 \%)$ & $2(8.3 \%)$ & $2(6.9 \%)$ & $8(7.3 \%)$ \\
\hline Middle Eastern & & & $1(4.2 \%)$ & $2(6.9 \%)$ & $3(2.8 \%)$ \\
\hline Native American & & $2(6.7 \%)$ & & & $2(1.8 \%)$ \\
\hline Other/mixed & $2(7.7 \%)$ & $2(6.7 \%)$ & & $2(6.9 \%)$ & $6(5.5 \%)$ \\
\hline No response & & $1(3.3 \%)$ & $2(8.3 \%)$ & $1(3.4 \%)$ & $4(3.7 \%)$ \\
\hline \multicolumn{6}{|l|}{ Relation to $A D$} \\
\hline Grandchild of person with AD & $11(42.3 \%)$ & $11(36.7 \%)$ & $7(29.2 \%)$ & $10(34.4 \%)$ & $39(35.8 \%)$ \\
\hline Child of person with AD & & $2(6.7 \%)$ & $1(4.2 \%)$ & $2(6.9 \%)$ & $5(4.6 \%)$ \\
\hline Other relative with $A D$ & $4(15.4 \%)$ & $4(13.3 \%)$ & $8(33.3 \%)$ & $5(17.2 \%)$ & $21(19.2 \%)$ \\
\hline No personal connection & $10(38.5 \%)$ & $12(40 \%)$ & $8(33.3 \%)$ & $12(41.4 \%)$ & $42(38.5 \%)$ \\
\hline No response & $1(3.8 \%)$ & $1(3.3 \%)$ & & & $2(1.8 \%)$ \\
\hline \multicolumn{6}{|l|}{ Referral to AlzU } \\
\hline Instagram & $14(53.8 \%)$ & $10(33.3 \%)$ & $9(37.5 \%)$ & $9(31.0 \%)$ & $42(38.5 \%)$ \\
\hline Facebook & $3(11.5 \%)$ & $11(36.7 \%)$ & $7(29.2 \%)$ & $12(41.4 \%)$ & $33(30.2 \%)$ \\
\hline Twitter & & & & $1(3.4 \%)$ & $1(0.9 \%)$ \\
\hline Email & $2(7.7 \%)$ & $1(3.3 \%)$ & $1(4.2 \%)$ & $3(10.3 \%)$ & $7(6.4 \%)$ \\
\hline TV & $1(3.8 \%)$ & & $1(4.2 \%)$ & & $2(1.8 \%)$ \\
\hline YouTube & $1(3.8 \%)$ & $2(6.7 \%)$ & & $1(3.4 \%)$ & $4(3.7 \%)$ \\
\hline \multicolumn{6}{|l|}{ Parade magazine } \\
\hline \multicolumn{6}{|l|}{ Newspaper } \\
\hline Lecture & & $2(6.7 \%)$ & & & $2(1.8 \%)$ \\
\hline Website & $2(7.7 \%)$ & $1(3.3 \%)$ & $2(8.3 \%)$ & $1(3.4 \%)$ & $6(5.5 \%)$ \\
\hline No response & $3(11.5 \%)$ & $3(10 \%)$ & $4(15.4 \%)$ & $2(6.9 \%)$ & $12(11.0 \%)$ \\
\hline
\end{tabular}


Table 1 Baseline demographics of college and high school students (continued)

\begin{tabular}{|c|c|c|c|c|c|}
\hline Variable & Celebrity webinar & Celebrity video & Doctor webinar & Control & Total \\
\hline High school & $n=42$ & $n=48$ & $n=46$ & $\mathrm{n}=36$ & $\mathrm{n}=172$ \\
\hline Age, $y$, mean & 16.2 & 16.7 & 16.1 & 16.5 & 16.4 \\
\hline \multicolumn{6}{|l|}{ Year of education } \\
\hline Freshman & $4(9.5 \%)$ & $11(22.9 \%)$ & $12(26.1 \%)$ & $3(8.3 \%)$ & $30(17.4 \%)$ \\
\hline Sophomore & $6(14.3 \%)$ & & $2(4.3 \%)$ & $1(2.8 \%)$ & $9(5.2 \%)$ \\
\hline Junior & $16(38.1 \%)$ & $17(40.5 \%)$ & $20(43.5 \%)$ & $11(30.6 \%)$ & $64(37.2 \%)$ \\
\hline Senior & $16(38.1 \%)$ & $17(40.5 \%)$ & $12(26.1 \%)$ & 19 (52.8\%) & $64(37.2 \%)$ \\
\hline No response & & $3(6.3 \%)$ & & $2(5.6 \%)$ & $5(29.1 \%)$ \\
\hline \multicolumn{6}{|l|}{ Sex } \\
\hline Male & $19(45.2 \%)$ & $14(29.2 \%)$ & $18(39.1 \%)$ & $10(27.8 \%)$ & $61(35.5 \%)$ \\
\hline Female & $23(54.8 \%)$ & $34(70.9 \%)$ & $28(60.1 \%)$ & $26(72.2 \%)$ & $111(64.5 \%)$ \\
\hline \multicolumn{6}{|l|}{ Race } \\
\hline Caucasian & $13(30.9 \%)$ & $17(40.5 \%)$ & $15(32.6 \%)$ & $10(27.8 \%)$ & $55(32.0 \%)$ \\
\hline Hispanic/Latino & $16(38.1 \%)$ & $12(25.0 \%)$ & $14(30.4 \%)$ & $11(30.6 \%)$ & $53(30.8 \%)$ \\
\hline African American & $2(4.8 \%)$ & $1(2.1 \%)$ & $2(4.3 \%)$ & $2(5.6 \%)$ & $7(4.1 \%)$ \\
\hline Asian/Pacific Islander & $5(11.9 \%)$ & $8(16.7 \%)$ & $9(19.6 \%)$ & $10(27.8 \%)$ & $32(18.6 \%)$ \\
\hline Middle Eastern/Arabic & $2(4.8 \%)$ & $2(4.2 \%)$ & & & $4(2.3 \%)$ \\
\hline \multicolumn{6}{|l|}{ Native American } \\
\hline Other/mixed & $4(9.5 \%)$ & $4(8.3 \%)$ & $5(10.9 \%)$ & $3(8.3 \%)$ & $16(9.3 \%)$ \\
\hline No response & & $2(4.2 \%)$ & $1(2.2 \%)$ & & $3(1.7 \%)$ \\
\hline \multicolumn{6}{|l|}{ Relation to AD } \\
\hline Grandchild of person with AD & $12(28.6 \%)$ & $10(20.8 \%)$ & $6(13.0 \%)$ & $4(11.1 \%)$ & $32(18.6 \%)$ \\
\hline \multicolumn{6}{|l|}{ Child of person with AD } \\
\hline Other relative with $A D$ & $5(11.9 \%)$ & $5(10.4 \%)$ & $13(28.2 \%)$ & $2(5.6 \%)$ & $25(14.5 \%)$ \\
\hline No personal connection & $24(57.1 \%)$ & $31(64.6 \%)$ & $25(54.3 \%)$ & $30(83.3 \%)$ & $110(63.9 \%)$ \\
\hline No response & $1(2.4 \%)$ & $2(4.2 \%)$ & $2(4.3 \%)$ & & $5(29.1 \%)$ \\
\hline \multicolumn{6}{|l|}{ Referral to AlzU } \\
\hline Instagram & $18(42.9 \%)$ & $14(29.2 \%)$ & $18(39.1 \%)$ & $12(33.3 \%)$ & $62(36.0 \%)$ \\
\hline Facebook & $9(21.4 \%)$ & $8(16.7 \%)$ & $6(13.0 \%)$ & $8(22.2 \%)$ & $31(18.1 \%)$ \\
\hline Twitter & $1(2.4 \%)$ & $1(2.1 \%)$ & & & $2(1.2 \%)$ \\
\hline Email & $2(4.8 \%)$ & $3(6.3 \%)$ & $4(8.7 \%)$ & $3(8.3 \%)$ & $12(6.9 \%)$ \\
\hline TV & & $3(6.3 \%)$ & & & $3(1.7 \%)$ \\
\hline YouTube & & $1(2.1 \%)$ & $1(2.2 \%)$ & $1(2.8 \%)$ & $3(1.7 \%)$ \\
\hline \multicolumn{6}{|l|}{ Parade magazine } \\
\hline Newspaper & & $1(2.1 \%)$ & & & $1(0.6 \%)$ \\
\hline Lecture & $8(19.0 \%)$ & $13(27.1 \%)$ & $13(28.2 \%)$ & $10(27.8 \%)$ & $44(25.6 \%)$ \\
\hline Website & $2(4.8 \%)$ & $4(8.3 \%)$ & $1(2.2 \%)$ & & $7(4.1 \%)$ \\
\hline No response & $2(4.8 \%)$ & & $3(6.5 \%)$ & $2(5.6 \%)$ & $7(4.1 \%)$ \\
\hline
\end{tabular}

Abbreviation: $A D=$ Alzheimer disease.

Values are $\mathrm{n}(\%)$ unless noted otherwise. 
Table 2 Change in quiz performance in college and high school users

\begin{tabular}{|c|c|c|c|c|}
\hline Measure & Celebrity webinar & Celebrity video & Doctor webinar & Control \\
\hline College & $n=26$ & $\mathrm{n}=30$ & $n=24$ & $\mathrm{n}=29$ \\
\hline Prelesson quiz total score (SD) & $3.54(2.61)$ & $3.37(2.88)$ & $3.92(3.36)$ & $4.24(2.83)$ \\
\hline Postlesson quiz total (SD) & $7.12(0.82)$ & $7.23(1.28)$ & $5.79(3.09)$ & $5.66(2.58)$ \\
\hline Change in score $(95 \% \mathrm{Cl})$ & $3.58(2.43-4.73)$ & $3.87(2.61-5.13)$ & $1.88(0.68-3.07)$ & $1.41(0.78-2.04)$ \\
\hline$p$ Value & $<0.01$ & $<0.01$ & $<0.01$ & $<0.01$ \\
\hline High school & $n=42$ & $\mathrm{n}=48$ & $\mathrm{n}=46$ & $\mathrm{n}=36$ \\
\hline Prelesson quiz total score (SD) & $4.62(2.46)$ & $5.29(2.62)$ & $4.80(2.09)$ & $5.03(1.89)$ \\
\hline Postlesson quiz total (SD) & $6.12(1.92)$ & $6.48(1.57)$ & $6.46(1.57)$ & $5.78(1.66)$ \\
\hline Change in score $(95 \% \mathrm{Cl})$ & $1.50(0.77-2.23)$ & $1.19(0.51-1.86)$ & $1.65(0.99-2.31)$ & $0.75(0.33-1.17)$ \\
\hline$p$ Value & $<0.01$ & $<0.01$ & $<0.01$ & $<0.01$ \\
\hline
\end{tabular}

Abbreviation: $\mathrm{Cl}=$ confidence interval.

school students, we found that college students saw greater improvements across multiple outcomes when the courses involved a celebrity. Ultimately, this study builds upon the growing body of evidence demonstrating that e-learning may be effective for education focused on general nutrition and exercise in younger populations, and particularly college students.

The celebrity video was more effective than the doctor webinar across multiple outcomes in college students, suggesting that celebrity voiceovers may enhance online learning formats greater than increasing lesson interactivity in this group. However, this result was not found in in high school students, suggesting that this effect may depend on various factors, such as familiarity with the celebrity among target audiences. ${ }^{14}$ Future studies are warranted to further understand these factors in an attempt to develop online education better suited for high school age students.

The overall baseline scores for the college and high school students are noteworthy. A prior study found that only $35 \%$ of college students correctly answered questions regarding $\mathrm{AD}$ risk factors. ${ }^{3}$ This gap in initial knowledge was also found in our study population, as the mean baseline scores for college (mean, 3.76; SD, 2.87) and high school students (mean, 4.94; SD, 2.30) were considerably low-this further demonstrates the importance of educating younger populations about $\mathrm{AD}$ and risk reduction, as there exists a distinct knowledge gap in this topic.

Our study has several limitations. AlzU.org offers 6 different courses (e.g., for physicians, medical students, etc.) While safeguards were in place to ensure users signed up for the correct course during the enrollment process, it is possible that the study populations did not include only currently enrolled high school and college students, and this may bias the results. Furthermore, study recruitment, as well as the entirety of study participation, was conducted online and may serve as a potential source of selection bias. While high school and college students may be more likely to have access to online platforms, this study is limited in its potential exclusion of participants who lack routine computer access or experience.

The course completion rates serve as another limitation, as $34.6 \%$ of college students and $42.4 \%$ of high school students completed the course. These participants may have been more motivated to complete the course than the general population, and may introduce bias to our results.

While the primary outcome was difference in pre vs post quiz scores, all demographics and secondary outcomes were collected via self-reported online surveys and are subject to reporting bias. Nevertheless, all such outcomes were compared against the control group in an attempt to mitigate this potential bias.

Given the overall postlesson quiz performances in both college (mean, 6.49; SD, 2.32) and high school (mean, 6.24; SD, 1.69), quiz difficulty may serve as a potential limitation. These questions were written by a team of health care professionals with prior experience in medical education, and were betatested in high school and college students. Nevertheless, these relatively low postlesson scores may suggest a degree of difficulty higher than we wished to achieve. Finally, given that completed lessons were followed immediately by the postquizzes, it is not yet clear whether the beneficial effects and knowledge gained by joining AlzU.org will persist with time. Future studies should examine the long-term effect of online education programs to better understand their effectiveness.

Our study suggests that online education involving a celebrity can be a useful strategy to educate younger populations about $\mathrm{AD}$ and risk reduction. As several studies have found that morphologic $\mathrm{AD}$-related changes begin in the brain decades 
Table 3 Comparison of lesson groups within college and high school students

\begin{tabular}{|c|c|c|c|c|}
\hline \multirow[b]{2}{*}{ Between-group comparisons } & \multicolumn{2}{|l|}{ College students } & \multicolumn{2}{|l|}{ High school students } \\
\hline & $\begin{array}{l}\text { Estimated difference }(95 \% \\
\text { confidence interval) }\end{array}$ & $\begin{array}{l}p \\
\text { Value }\end{array}$ & $\begin{array}{l}\text { Estimated difference }(95 \% \\
\text { confidence interval) }\end{array}$ & $\begin{array}{l}p \\
\text { Value }\end{array}$ \\
\hline \multicolumn{5}{|l|}{ Change in pre vs post quiz scores } \\
\hline Celebrity webinar vs control & 2.17 (0.87 to 3.46$)$ & $<0.01$ & TNP & TNP \\
\hline Celebrity video vs control & 2.46 (1.06 to 3.85$)$ & $<0.01$ & TNP & TNP \\
\hline Doctor webinar vs control & $0.465(-0.87$ to 1.80$)$ & 0.49 & TNP & TNP \\
\hline Celebrity webinar vs celebrity video & $-0.29(-1.95$ to 1.38$)$ & 0.73 & TNP & TNP \\
\hline Celebrity webinar vs doctor webinar & 1.70 (0.09 to 3.31$)$ & $<0.01$ & TNP & TNP \\
\hline Celebrity video vs doctor webinar & 2.00 (0.30 to 3.70$)$ & 0.02 & TNP & TNP \\
\hline \multicolumn{5}{|c|}{$\begin{array}{l}\text { "There are studies that prove exercise may reduce } \\
\text { AD risk" }\end{array}$} \\
\hline Celebrity webinar vs control & 1.44 (0.97 to 1.91$)$ & $<0.01$ & $0.66(0.14$ to 1.18$)$ & $<0.01$ \\
\hline Celebrity video vs control & 1.525 (1.03 to 2.02$)$ & $<0.01$ & $0.71(0.24$ to 1.18$)$ & $<0.01$ \\
\hline Doctor webinar vs control & $0.88(0.3$ to 1.46$)$ & $<0.01$ & 0.81 (0.35 to 1.27$)$ & $<0.01$ \\
\hline Celebrity webinar vs celebrity video & $-0.085(-0.65$ to 0.48$)$ & 0.76 & $-0.045(-0.51$ to 0.42$)$ & 0.50 \\
\hline Celebrity webinar vs doctor webinar & $0.555(-0.08$ to 1.19$)$ & 0.08 & $-0.145(-0.6$ to 0.31$)$ & 0.44 \\
\hline Celebrity video vs doctor webinar & $0.645(-0.01$ to 1.3$)$ & 0.06 & $-0.1(-0.49$ to 0.29$)$ & 0.89 \\
\hline \multicolumn{5}{|c|}{$\begin{array}{l}\text { "Studies have shown that diet may help with AD } \\
\text { and memory loss" }\end{array}$} \\
\hline Celebrity webinar vs control & 1.375 (0.88 to 1.87$)$ & $<0.01$ & $0.51(-0.02$ to 1.04$)$ & 0.01 \\
\hline Celebrity video vs control & 1.225 (0.7 to 1.75$)$ & $<0.01$ & 0.675 (0.19 to 1.16$)$ & $<0.01$ \\
\hline Doctor webinar vs control & $0.82(0.26$ to 1.38$)$ & $<0.01$ & 0.705 (0.2 to 1.21$)$ & $<0.01$ \\
\hline Celebrity webinar vs celebrity video & $0.155(-0.47$ to 0.78$)$ & 0.63 & $-0.165(-0.65$ to 0.32$)$ & 0.84 \\
\hline Celebrity webinar vs doctor webinar & $0.555(-0.1$ to 1.21$)$ & 0.10 & $-0.19(-0.69$ to 0.31$)$ & 0.52 \\
\hline Celebrity video vs doctor webinar & $0.4(-0.27$ to 1.07$)$ & 0.24 & $-0.03(-0.48$ to 0.42$)$ & 0.62 \\
\hline \multicolumn{5}{|l|}{ Hopeful about the future of $A D$ research } \\
\hline Celebrity webinar vs control & $1.26(0.73$ to 1.79$)$ & $<0.01$ & TNP & TNP \\
\hline Celebrity video vs control & 1.125 (0.58 to 1.67$)$ & $<0.01$ & TNP & TNP \\
\hline Doctor webinar vs control & $0.475(-0.21$ to 1.16$)$ & 0.17 & TNP & TNP \\
\hline Celebrity webinar vs celebrity video & $0.14(-0.16$ to 0.44$)$ & 0.36 & TNP & TNP \\
\hline Celebrity webinar vs doctor webinar & $0.785(0.25$ to 1.32$)$ & $<0.01$ & TNP & TNP \\
\hline Celebrity video vs doctor webinar & 0.65 (0.1 to 1.2$)$ & 0.02 & TNP & TNP \\
\hline \multicolumn{5}{|c|}{ "I am likely to pursue a career in health care" } \\
\hline Celebrity webinar vs control & 0.955 (0.47 to 1.44$)$ & $<0.01$ & TNP & TNP \\
\hline Celebrity video vs control & 0.98 (0.52 to 1.44$)$ & $<0.01$ & TNP & TNP \\
\hline Doctor webinar vs control & $0.515(-0.07$ to 1.1$)$ & 0.09 & TNP & TNP \\
\hline Celebrity webinar vs celebrity video & $-0.025(-0.36$ to 0.31$)$ & 0.87 & TNP & TNP \\
\hline Celebrity webinar vs doctor webinar & $0.24(-0.46$ to 0.94$)$ & 0.8 & TNP & TNP \\
\hline Celebrity video vs doctor webinar & 0.465 (-0.007 to 0.94$)$ & 0.04 & TNP & TNP \\
\hline
\end{tabular}


Table 3 Comparison of lesson groups within college and high school students (continued)

\begin{tabular}{|c|c|c|c|c|}
\hline \multirow[b]{2}{*}{ Between-group comparisons } & \multicolumn{2}{|l|}{ College students } & \multicolumn{2}{|l|}{ High school students } \\
\hline & $\begin{array}{l}\text { Estimated difference }(95 \% \\
\text { confidence interval) }\end{array}$ & $\begin{array}{l}p \\
\text { Value }\end{array}$ & $\begin{array}{l}\text { Estimated difference }(95 \% \\
\text { confidence interval) }\end{array}$ & $\begin{array}{l}p \\
\text { Value }\end{array}$ \\
\hline \multicolumn{5}{|c|}{$\begin{array}{l}\text { "I am likely to promote awareness and raise } \\
\text { money for AD" }\end{array}$} \\
\hline Celebrity webinar vs control & $1.12(0.49$ to 1.75$)$ & $<0.01$ & TNP & TNP \\
\hline Celebrity video vs control & $0.98(0.43$ to 1.53$)$ & $<0.01$ & TNP & TNP \\
\hline Doctor webinar vs control & $0.525(-0.17$ to 1.22$)$ & 0.14 & TNP & TNP \\
\hline Celebrity webinar vs celebrity video & $0.14(-0.44$ to 0.72$)$ & 0.63 & TNP & TNP \\
\hline Celebrity webinar vs doctor webinar & $0.6(-0.12$ to 1.32$)$ & 0.10 & TNP & TNP \\
\hline Celebrity video vs doctor webinar & $0.46(-0.19$ to 1.11$)$ & 0.16 & TNP & TNP \\
\hline \multicolumn{5}{|c|}{$\begin{array}{l}\text { "I plan to recommend the course to family \& } \\
\text { friends" }\end{array}$} \\
\hline Celebrity webinar vs control & $-0.38(-0.57$ to -0.19$)$ & $<0.01$ & TNP & TNP \\
\hline Celebrity video vs control & $-0.315(-0.52$ to -0.11$)$ & $<0.01$ & TNP & TNP \\
\hline Doctor webinar vs control & $-0.05(-0.32$ to 0.22$)$ & 0.74 & TNP & TNP \\
\hline Celebrity webinar vs celebrity video & $-0.065(-0.16$ to 0.03$)$ & 0.16 & TNP & TNP \\
\hline Celebrity webinar vs doctor webinar & $-0.335(-0.54$ to -0.13$)$ & $<0.01$ & TNP & TNP \\
\hline Celebrity video vs doctor webinar & $-0.27(-0.49$ to -0.05$)$ & 0.02 & TNP & TNP \\
\hline
\end{tabular}

Abbreviations: $\mathrm{AD}=$ Alzheimer disease; $\mathrm{TNP}=$ test not performed.

One-way analysis of variance (ANOVA) was used to compare differences pre vs post among the lesson groups. In cases where change in score differed significantly between the groups $(p<0.05)$, post hoc $t$ tests were performed to assess for specific group differences. Outcomes that did not have significant differences found via ANOVA have post hoc $t$ test values reported as TNP.

before onset of neurodegenerative symptoms, it is essential to educate high school and college students on brain-healthy lifestyles that may reduce $\mathrm{AD}$ risk. ${ }^{1}$

\section{Study funding}

This research was funded by philanthropic support by Hilarity for Charity; proceeds from the Annual Memories for Mary fundraiser organized by David Twardock; Zuckerman Family Foundation; Women's Alzheimer's Movement; contributions from patients of the Alzheimer's Prevention Clinic, Weill Cornell Memory Disorders Program; and grant funding by the Weill Cornell Medicine Clinical and Translational Science Center (NIH/NCATS \#UL1TR002384).

\section{Disclosure}

The authors report no disclosures relevant to the manuscript. Go to Neurology.org/N for full disclosures.

\section{Appendix Authors}

\begin{tabular}{lll}
\hline Name & Location & Contribution \\
\hline $\begin{array}{ll}\text { Nabeel Saif, } \\
\text { MS }\end{array}$ & $\begin{array}{l}\text { Weill Cornell Medicine, } \\
\text { New York }\end{array}$ & $\begin{array}{l}\text { Study design, data collection, } \\
\text { drafting of the manuscript, } \\
\text { data interpretation }\end{array}$ \\
\hline
\end{tabular}

\section{Appendix (continued)}

\begin{tabular}{|c|c|c|}
\hline Name & Location & Contribution \\
\hline $\begin{array}{l}\text { Kellyann } \\
\text { Niotis, MD }\end{array}$ & $\begin{array}{l}\text { Weill Cornell Medicine, } \\
\text { New York }\end{array}$ & $\begin{array}{l}\text { Study design, data collection, } \\
\text { data interpretation, critical } \\
\text { revision of the manuscript }\end{array}$ \\
\hline $\begin{array}{l}\text { Moises } \\
\text { Dominguez, } \\
\text { MD }\end{array}$ & $\begin{array}{l}\text { Weill Cornell Medicine, } \\
\text { New York }\end{array}$ & $\begin{array}{l}\text { Study design, data } \\
\text { interpretation, critical } \\
\text { revision of the manuscript }\end{array}$ \\
\hline $\begin{array}{l}\text { John F. } \\
\text { Hodes }\end{array}$ & $\begin{array}{l}\text { Pacific Neuroscience } \\
\text { Institute, Los Angeles }\end{array}$ & $\begin{array}{l}\text { Data interpretation and } \\
\text { revision of the manuscript }\end{array}$ \\
\hline $\begin{array}{l}\text { Michael } \\
\text { Woodbury }\end{array}$ & $\begin{array}{l}\text { Harvard Medical School, } \\
\text { Boston }\end{array}$ & $\begin{array}{l}\text { Data interpretation and } \\
\text { revision of the manuscript }\end{array}$ \\
\hline $\begin{array}{l}\text { Yasmin } \\
\text { Amini }\end{array}$ & $\begin{array}{l}\text { Columbia University, } \\
\text { New York }\end{array}$ & $\begin{array}{l}\text { Data interpretation and } \\
\text { revision of the manuscript }\end{array}$ \\
\hline $\begin{array}{l}\text { George } \\
\text { Sadek, BA }\end{array}$ & $\begin{array}{l}\text { Weill Cornell Medicine, } \\
\text { New York }\end{array}$ & Revision of the manuscript \\
\hline $\begin{array}{l}\text { Olivia } \\
\text { Scheyer, BA }\end{array}$ & $\begin{array}{l}\text { School of Law, University } \\
\text { of California Los Angeles, } \\
\text { Los Angeles }\end{array}$ & $\begin{array}{l}\text { Data collection and } \\
\text { measurement of the sample }\end{array}$ \\
\hline $\begin{array}{l}\text { Emily } \\
\text { Caesar, BA }\end{array}$ & $\begin{array}{l}\text { Loyola School of } \\
\text { Medicine, Chicago }\end{array}$ & $\begin{array}{l}\text { Data collection and } \\
\text { measurement of the sample }\end{array}$ \\
\hline $\begin{array}{l}\text { Hollie } \\
\text { Hristov, FNP }\end{array}$ & $\begin{array}{l}\text { Weill Cornell Medicine, } \\
\text { New York }\end{array}$ & Revision of the manuscript \\
\hline
\end{tabular}




\begin{tabular}{lll} 
Appendix & (continued) & \\
\hline Name & Location & Contribution \\
\hline $\begin{array}{l}\text { Newman } \\
\text { Knowlton, } \\
\text { MS }\end{array}$ & $\begin{array}{l}\text { Biostatistics, Pentara } \\
\text { Corporation, Salt Lake } \\
\text { City }\end{array}$ & Statistical analyses \\
\hline Paige Lee & $\begin{array}{l}\text { University of California } \\
\text { Los Angeles, Los Angeles }\end{array}$ & Revision of the manuscript \\
\hline $\begin{array}{l}\text { Mark } \\
\text { Mclnnis, BA }\end{array}$ & $\begin{array}{l}\text { Weill Cornell Medicine, } \\
\text { New York }\end{array}$ & $\begin{array}{l}\text { Study design and } \\
\text { measurement of the sample }\end{array}$ \\
\hline $\begin{array}{l}\text { Richard } \\
\text { Isaacson, } \\
\text { MD }\end{array}$ & $\begin{array}{l}\text { Weill Cornell Medicine, } \\
\text { New York }\end{array}$ & $\begin{array}{l}\text { Study design, data collection, } \\
\text { data interpretation, drafting, } \\
\text { revision of the manuscript }\end{array}$ \\
\hline
\end{tabular}

\section{References}

1. 2019 Alzheimer's disease facts and figures. Alzheimers Demen 2019;15:321-387.

2. Livingston G, Sommerlad A, Orgeta V, et al. Dementia prevention, intervention, and care. Lancet 2017;390:2673-2734.

3. Eshbaugh EM. Gaps in Alzheimer's knowledge among college students. Educ Gerontol 2014;40:655-665.
4. Escoffery C, Miner KR, Adame DD, Butler S, McCormick L, Mendell E. Internet use for health information among college students. J Am Coll Health 2005;53:183-188. 5. Suminski RR, Petosa R. Web-assisted instruction for changing social cognitive variables related to physical activity. J Am Coll Health 2006;54:219-226.

6. LaChausse RG. My student body: effects of an internet-based prevention program to decrease obesity among college students. J Am Coll Health 2012;60:324-330.

7. Isaacson RS, Haynes N, Seifan A, et al. Alzheimer's prevention education: if we build it, will they come? J Prev Alzheimers Dis 2014;1:91-98.

8. Newcomb MD, Antoine Mercurio C, Wollard CA. Rock stars in anti-drug-abuse commercials: an experimental study of adolescents' reactions. J Appl Soc Psychol 2000;30:1160-1185.

9. Keys TR, Morant KM, Stroman CA. Black youth's personal involvement in the HIV AIDS issue: does the public service announcement still work? J Health Commun 2009; 14:189-202.

10. de Leeuw A, Valois P, Ajzen I, Schmidt P. Using the theory of planned behavior to identify key beliefs underlying pro-environmental behavior in high-school students: implications for educational interventions. J Environ Psychol 2015;42:128-138.

11. Isaacson RS, Seifan A, Haddox CL, et al. Using social media to disseminate education about Alzheimer's prevention \& treatment: a pilot study on Alzheimer's Universe. J Commun Healthc 2018;11:106-113.

12. Larsen DP, Butler AC, Aung WY, Corboy JR, Friedman DI, Sperling MR. The effects of test-enhanced learning on long-term retention in AAN annual meeting courses. Neurology 2015;84:748-754.

13. Kanner RM, Alcauskas M. Is the medium the message, or is more better? Neurology 2011;76:115-116.

14. Hoffman SJ, Mansoor Y, Natt N, et al. Celebrities' impact on health-related knowledge, attitudes, behaviors, and status outcomes: protocol for a systematic review, meta-analysis, and meta-regression analysis. Syst Rev 2017;6:13. 


\section{Neurology}

\section{Education Research: Online Alzheimer education for high school and college students: \\ A randomized controlled trial}

Nabeel Saif, Kellyann Niotis, Moises Dominguez, et al.

Neurology 2020;95;e2305-e2313 Published Online before print July 14, 2020

DOI 10.1212/WNL.0000000000009859

This information is current as of July 14, 2020

\section{Updated Information \&} Services

References

Subspecialty Collections

Permissions \& Licensing

Reprints including high resolution figures, can be found at: http://n.neurology.org/content/95/16/e2305.full

This article cites 14 articles, 2 of which you can access for free at: http://n.neurology.org/content/95/16/e2305.full\#ref-list-1

This article, along with others on similar topics, appears in the following collection(s):

Alzheimer's disease

http://n.neurology.org/cgi/collection/alzheimers_disease Computer use in education

http://n.neurology.org/cgi/collection/computer_use_in_education Methods of education

http://n.neurology.org/cgi/collection/methods_of_education

Information about reproducing this article in parts (figures,tables) or in its entirety can be found online at:

http://www.neurology.org/about/about_the_journal\#permissions

Information about ordering reprints can be found online:

http://n.neurology.org/subscribers/advertise

Neurology ${ }^{\circledR}$ is the official journal of the American Academy of Neurology. Published continuously since 1951, it is now a weekly with 48 issues per year. Copyright @ 2020 American Academy of Neurology. All rights reserved. Print ISSN: 0028-3878. Online ISSN: 1526-632X.

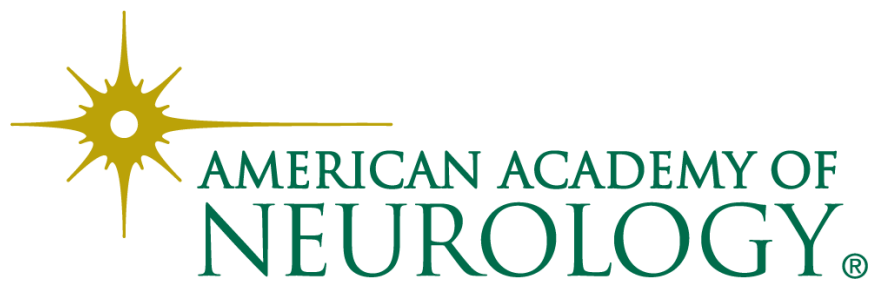

